This is an open access article under the CC BY-NC-ND license (https://creativecommons.org/licenses/by-nc-nd/3.0/) Issue II, November 2019

ISBN 978-601-323-144-0

https://doi.org/10.31643/2019.001

\author{
Merjen Atayeva \\ Yogyakarta State University, Indonesia \\ E-mail: merjen0004pasca.2018@ student.uny.ac.id \\ ORCID ID 0000-0002-5090-4687
}

\author{
Gulzhaina Kassymova \\ Abai Kazakh National Pedagogical \\ University \& Satbayev University, Kazakhstan \\ E-mail: zhaina.kassym@gmail.com \\ ORCID ID 0000-0001-7004-3864
}

\author{
Putro Nur Hidayanto Pancoro Setyo \\ Yogyakarta State University, Indonesia \\ E-mail: nur_hidayanto@uny.ac.id \\ ORCID ID 0000-0002-3019-8498
}

\author{
Saida Kosbay \\ Abai Kazakh National Pedagogical University \\ Almaty, the Republic of Kazakhstan \\ E-mail: k.saiida.97@ mail.ru \\ ORCID ID 0000-0001-6723-8070
}

\title{
Impact of reading on students' writing ability
}

\begin{abstract}
For college students, reading and writing are very necessary for the success of their studies. Reading habit can severe their knowledge and comprehension in their field of subjects. This study sets out to investigate how students' reading skills affect students' academic writing. Fifty-two master students of English Language Education at Universitas Ahmad Dahlan in Yogyakarta, Indonesia were involved in this correlational study. Two questionnaires were used as instruments to obtain the data, i.e., the reading habit survey and the academic writing skill survey. The data were analyzed with descriptive statistics and single linear regression tests along with the prerequisite test of normality. The results revealed that the reading habit and writing skills of the students were at the medium level. Meanwhile, the other result showed that the reading habit had a profound effect on college students' academic writing skill shown by the p-value of T-test $=0.000$ and $F$ score $=352,524$ at the significant $0,000 \leq 0,05$. In other words, reading habit has a significant influence on college students' academic writing skill.
\end{abstract}

Keywords: Reading habit, academic writing, students, cognitive skills and competence.

Introduction. For college students, reading and writing are very necessary for the successful study. Since writing is the act of transmitting knowledge in print, the students, therefore, must have information to share before they write (Suskie, 2018). Krashen (2016), mentions that we do not learn to write by writing, but rather by reading. It means reading and writing are substantially related to each other both concurrently and longitudinally. Firstly, secondary school level, for example, the free volunteer reading activities in their schools increased their reading comprehension, their writing style, their vocabulary, their spelling and their grammatical development (Arndt \& Woorw, 2018). To Indonesian college students, however, writing in English has been a common problem due to insufficient exposure to English texts, different culture, and different reading habit (Connor, 1996; Dardjowidjojo, 1997; Grabe \& Kaplan, 1996; Imran, 2005; Kridalaksana, 2002; Sukandi, 2013).

The term "reading habit" denotes to the manner which indicates the similarity of reading of person's styles of reading, tastes of reading, activity repeatedly carried out (Fatiloro, Adesola, Hameed, \& Adewumi, 2017). It is assumed that the students who read more will also write better than those who don't (Cottrell, 2017). Low level of reading habit had been accused as the cause of a small number of published articles written by Indonesian college students (Iswandari, 2013; Wahyuni, Oktavia, \& Marlina, 2019; and Wibowo, 2015). According to Cahyono \& Widiati (2006 in Ayun \& Yunus, 2017) university students in Indonesia lack of interest in reading classes since they are not familiar with explanation and discussion genres which are commonly used in reading.

Since not many studies have been done on the effect of reading habit to the problem of academic writing made by college students of English Language Teaching Education, a thorough investigation pertinent to this is needed to be conducted as they are going to be professional English teachers.

The research problems are formulated as follows:

$>$ What is the degree of college students' reading habit and academic writing skills?

$>$ Is there any significant effect of college students' reading habit on their academic writing? 


\section{Literature review}

Academic Writing. By its definition, writing is the production of communication, linking ideas, and information development, or giving arguments to a particular reader or a group of readers (Hedge, 2005). This definition implies that writing is the production of the ideas expressed in the written form. Before producing the writing, the writer needs to receive and process information as much as possible. This assumption is in line with Kellogg's ideas that writing is a major cognitive challenge, because it is at once a test of memory, language, and thinking ability (Kellogg, 2018).

Bailey (2003), in particular, mentions that academic writing is the course which is designed for college students to learn how to write effectively as they have to do the college writing assignments for exam, coursework, thesis, or final project report. The process of academic writing is started from choosing a topic, writing an introductory paragraph, paragraph development, and concluding paragraph. All those paragraphs can be in the form of argumentative, descriptive, narrative, expository essay, paper, report, project portfolio, a case study or a dissertation (Redman \& Maples, 2017).

The purpose of writing in an academic setting is different from that of non-academic one. Writing to a friend, for example, is aimed at informing him/her about the writer's condition; and writing a funny story, the main purpose is usually to entertain the reader. In the academic setting, however, the purpose of writing is to express thoughts in a logical and critical way (Horkoff, 2015). The quality of academic writing, therefore, is determined by the writer's information, structural, transactional, aesthetic, and process knowledge (Rubin \& Hansen, 1984 in Hattab, 2018). There are of course some reasons why college students in Indonesia have a problem with writing skills. Among the reasons may be English grammar skill, lack of English vocabularies, and less writing practice. Students tend to translate directly from Bahasa Indonesia into English or use google translation for their writing assignments. They frequently write ambiguity statement that sometimes has no sense or difficult to understand (Ariayanti, 2016 in Husin \& Nurbayani, 2017).

Reading habit. The term "reading habit" refers to the behavior which expresses the likeness of reading of individual types of reading, and tastes of reading (Fatiloro, Adesola, Hameed, \& Adewumi, 2017). It is a pattern with which an individual organizes his or her reading. It is repeated behavior that becomes an automatic action without purposeful thinking to do and there is no sense of awareness (McKnight \& Allen,

2018).

Reading habit can be categorized into very low, rather low, medium, high, and very high (Anderson, 1981, in Ellis, 2016). It is measured from several aspects such as the number of reading practices, vast amount of time provided for reading, good proficiency in English (Ogeyik \& Akyay, 2009 in Kanmani \& Muniandy, 2013; and Renandya, 2007 in Januarty, 2018), positive attitude toward reading, conscious and avid reading (Park, 2011), self-selection of books, motivation to read, eagerness to receive a book as a present (Jamnik, 2005 in Iftanti, 2015), and regular reading after school hours (Adetunji \& Oladeji, 2007 in Iftanti, 2015).

Based on a research conducted by Miller (2016) president of Central Connecticut State University, on the literate behaviors and their supporting resources such as size and number of libraries and newspaper readership of the people in more than 60 countries, it is found the Nordic countries (Finland, Norway, Iceland, Denmark, and Sweden,) are among the five most literate nations in the world, while the U.S. and Canada rank 7th and 11th respectively while Indonesia has the rank at the 60th out of 61 countries in terms of reading habits. Indonesian reading habit is below that of Thailand and above Botswana. Among 1.000 Indonesian people, only 1 person reads books on a regular basis or for leisure.

Students in Indonesia do not belong to heavy readers who read numerous texts or novels as much as possible and as many times as possible in a month. They do not also include moderate readers who read same texts and novels as seen useful for them or inactive readers those who like to read and they regard themselves as readers. Indonesian people do not take the time to read regularly. Indonesian people like spending much of their time (431 minutes /day $=7$ hours/day) watching video or movie more than a global viewer of 402 minutes/day (Noviadhista, 2016).

Reading Habit and Writing Skill of Indonesian College Students. There have been some researches on the relationship between reading habit toward vocabulary mastery of the English language of college students (Santoso, 2015), reading habit and reading comprehension (Muawanah, 2014), reading habit and speaking skill (Akbar, 2014), Reading habit and writing skill (Juriati, Ariyanti, \& Fitriana, 2018), Reading 
habit and critical thinking of college students (Suhartono, 2014). These mean that there are always such investigations or research related to reading and writing in Indonesian context. Moreover, there are also some reasons why EFL students have a problem with writing skills, especially for Indonesian college students. Among the reasons are structural, grammatical, and style differences between Bahasa (Indonesian language) and English language. Students try to translate directly from Bahasa Indonesia into English. In this case, students frequently produce a statement which some time has no sense or difficult for readers to understand (Ariayanti, 2016 in Husin \& Nurbayani, 2017)

One study conducted on 546 EFL college students in East Java showed that less than $25 \%$ of them read outside the classroom (Nazhari \& Delfi, 2016). Then, based on a study conducted by Mustafa (2012) to the students of English Language Study Program at the University of Riau, such low reading habit was influenced by Indonesian tradition of spoken culture. Those findings are also in line with Adetunji (2007) statement that personal characteristics of the students including age distribution, social class, and parents' occupation are determinant factors for reading habit among high school students. Nevertheless, Nathanson, Pruslow, and Levitt (2008) found evidence that parents have a more powerful effect in creating enthusiastic readers among the students. Another factor is the accessibility to electronic facilities such as the internet (Ogeyik \& Akyay, 2009).

Reading habits of college students in other countries, however, are connected with students' gender and age. Schwabe, McElvany, and Trendtel, (2015) and Putro \& Lee (2017) also showed that females as substantial readers compare to males or girls performed better than boys. Clark and Foster (2005, in Florence, 2017) expose that boys most times don't enjoy reading and have a negative attitude toward reading but girls mostly vice versa. In term of amount of time used for reading, the studies in the USA specify that college students don't read more than 2 hours in a day (Blackwood, 1991 in Florence, 2017) and Dipika and Md. Mehedi (2013) exposes that men usually prefer reading newspapers compared to women.

\section{Research Hypothesis of the Research}

Based on the literature review above, the research hypothesis is formulated as follows:

$>$ There is a significant effect of reading habit on the academic writing of students of English Language Education of Universitas Ahmad Dahlan (UAD).

Advantages of the Research. Since the study was conducted before the process of teaching and learning at the graduate program, the professor who teaches "Thesis Writing Proposal" can get thorough information on the prior-writing skill of his master students. He or she, then, can develop instructional activities to improve reading habit and writing skill of the students.

\section{Method}

Participants. Participants were 52 college students of graduate programs of English Language and Education at Universitas Ahmad Dahlan (UAD), Yogyakarta. The participants were taken randomly from the total population of 76 students. They consisted of 25 males and 27 females. In addition, the participants had already finished all the compulsory courses including reading, writing and thesis proposal writing offered by the English Language and Education at UAD. They were also chosen since they are demanded to write an academic writing in the form of a master thesis. They need to read a lot of resources for accomplishing their writing.

Data Analysis and Procedure. This study employed questionnaires as instruments. The two questionnaires were: the adapted questionnaire from Iftanti (2012) and "The European Writing Survey (EUWRIT)" by Chitez et al. (2018). The questionnaires used several types of scales ranging from open questions to 5 point Likert scales. The questionnaires were distributed to 52 students of UAD, Yogyakarta before they started the course. Additionally, the researcher used self-enumeration technique in which they answered all items in the questionnaire without any assistance from the researcher. Regarding the validity and reliability of the instrument, they were examined by using SPSS 20 (Cronbach Alpha) with reliability coefficient bigger than $r$ table 0,349 . The data were analyzed in term of percentages, mean scores, standard deviation (SD), regression coefficients, and analysis of variance (ANOVA).

Prerequisite Test. Prerequisite tests were used to test the normality of the data. The results showed that the data from those two instruments were normal with a significant score of Kolmogorov-Smirnov test above 0.05. Data in Iftanti (2012) instrument (X) obtained 0.728 in Kolmogorov-Smirnov test while the data 
of Chitez's et al. instrument (Y) (2018) got 0.549 in Kolmogorov-Smirnov test. They can be seen in Table 1 as follows:

Table 1. One-Sample Kolmogorov-Smirnov Test

\begin{tabular}{|c|c|c|}
\hline & $\mathbf{X}$ & $\mathbf{Y}$ \\
\hline $\mathbf{N}$ & 52 & 52 \\
\hline Normal parameters $\mathbf{s}^{\mathrm{a}, \mathrm{b}}$ & 141,8269 & 120,6538 \\
\hline Std. Deviation & 10,05421 & 8,98776 \\
\hline Absolute &, 101 &, 076 \\
\hline Most Extreme Differences Positive & 060 & 062 \\
\hline Negative &,- 101 &,- 076 \\
\hline Kolmogorov-Smirnov Z &, 728 &, 549 \\
\hline Asymp. Sig. (2 tailed) & 664 & 923 \\
\hline
\end{tabular}

\section{Findings and discussions}

Research Question 1: What is the degree of reading habit and academic writing skill of college students of English Language Education at UAD? The results of the study are structured from general descriptive of the students, amount of time given for reading practice, types of texts they read, source of their reading text, other books they read, the number of published writings in national and international journals.

The students who took the course "Thesis Writing Proposal" at the graduate program of English Language Education, UAD are graduated from Bachelor of English Language Education of different colleges in Indonesia. Only two students (3.84 \%) have the profession as English Language teachers at junior and senior high schools. They have taught the English Language for five years. It means that most of them $(96,15 \%)$ are undergraduates without any professions.

Pertinent to a questionnaire administered, it is found that their writing skill has low means score compared to that of reading habit (see Table 2). This is based upon the results of the questionnaire given to 52 college students at the Graduate Program of English Language Teaching. The detail is explained that that writing skill variable (Y) has a minimum score of 94 and a maximum score of 140 with means 120,65 and standard deviation of 8,98 . Then reading habit variable $(\mathrm{X})$ shows a minimum score of 114 and maximum score 165 with means 141,83 and standard deviation 10,054 .

Table 2. Descriptive Statistics

\begin{tabular}{lll}
\hline & \multicolumn{1}{c}{$\begin{array}{c}\text { X } \\
\text { (reading habit) }\end{array}$} & $\begin{array}{c}\text { Y } \\
\text { (writing skill) }\end{array}$ \\
\hline N Valid $\quad$ Missing & 52 & 52 \\
Mean & 0 & 0 \\
Std. Deviation & 141,8269 & 120,6538 \\
Variance & 10,05421 & 8,98776 \\
Range & 101,087 & 80,780 \\
Minimum & 51,00 & 46,00 \\
Maximum & 114,00 & 94,00 \\
\hline
\end{tabular}

Source: Primary data

Since these two results indicate that the reading habit owned by the college students of UAD is higher than that of academic writing skill, therefore, it can be meant that they have already practiced well on their ability to read more about English books, texts such as newspaper, magazines, leaflets, comics, and many others. In relation to this, these results also in line with the findings of Iftanti (2012) that the more the students read a lot the more knowledge they will gain. In other words, the college students of UAD are aware of the need to elevate their English reading skill. This activity can be categorized as the basic learning to conquer about other skills pertinent to reading habit (Erdem, 2014). 
Meanwhile, referring to the questionnaires on writing skill distributed to the 52 college students, it is found that the highest score is 140 and the lowest score is 94 with means of 120,65. The percentage of the writing skill of the college students belong to the medium/neutral level. For detail, it can be seen in Table 3 . This level indicates that the college student of (UAD) still like to write in English, to plan before they start writing, to read the materials at first then continue to put their idea into their writing. Further, this level clearly shows that the college students are able to utilize their competence to write well such as adjusting the structures of paragraphs, creating good sentences which are all depending on what they have learned. One scholar ever says that the aim of a writing is to express the idea logically and to encourage one's critical way of thinking (Horkof, 2015).

Table 3.Variable description of Academic Writing Skills

\begin{tabular}{clll}
\hline Class interval & Frequency & \multicolumn{1}{c}{ Percentage } & \multicolumn{1}{c}{ Categories } \\
\hline $\mathbf{9 4 - 1 0 3}$ & 2 & 3.85 & Lowest \\
$\mathbf{1 0 4 - 1 1 3}$ & 110 & 19.23 & Rather low \\
$\mathbf{1 1 4 - 1 2 3}$ & 22 & 42.30 & Neutral \\
$\mathbf{1 2 4 - 1 3 3}$ & 15 & 28.85 & Rather high \\
$\mathbf{1 3 4 - 1 4 3}$ & 3 & 5.77 & Highest \\
& & & \\
& & & \\
\hline Total & $\mathbf{5 2}$ & $\mathbf{1 0 0}$ & \\
\hline
\end{tabular}

Moreover, the detailed description of reading habit of 52 college students of UAD is exhibited in Table 4. It is shown that their reading habit is also at a medium/neutral level. It is shown by the "mean" score $(141,8269)$ which is then converted into class interval. The detail can be seen in Table 4. This level expresses that the college students of UAD have boosted their reading habit through reading various kinds of texts such as short story, drama, novel, fairy tales, and textbooks on various topics, letters, and many others. These are based on the items on the questionnaires. These kinds of activities imply that they have a good reading habit (Iftanti, 2012).

Table 4. Variable description of Reading Habits

\begin{tabular}{clll}
\hline Class interval & Frequency & \multicolumn{1}{c}{ Percentage } & Categories \\
\hline $\mathbf{1 1 4 - 1 2 4}$ & 2 & 3.85 & Lowest \\
$\mathbf{1 2 5 - 1 3 5}$ & 12,23 & 44,23 & Rather low \\
$\mathbf{1 3 6 - 1 4 6}$ & 12 & 23.08 & Neutral \\
$\mathbf{1 4 7 - 1 5 7}$ & 13 & 24.99 & Rather high \\
$\mathbf{1 5 8 - 1 6 8}$ & 2 & 3.85 & Highest \\
& & & \\
& & & \\
\hline Total & $\mathbf{5 2}$ & $\mathbf{1 0 0}$ & \\
\hline
\end{tabular}

In addition, it is revealed from the study that more than half of the students or $65.5 \%$ out of 23 students affirmed that they read textbooks in their areas of specialization if assigned by the professor. They rarely read motivational books, novels, books, and informational/current affairs on a daily basis. Interestingly $83.0 \%$ of them read from internet resources when given a daily assignment. Only $12.5 \%$ of them read magazines once a month.

In term of length of time for reading activities, the statistical data imply that the respondents' reading habits are low (rather low and low $=48,08 \%)$. There are only 15 students $(28,845 \%)$ respondents who read four hours or more every day. Spending at least four until more than five hours every day can reflect their interest in reading practice. This indicates that only less than $50 \%$ of the students have good reading habits.

Students do not belong to the: 
$>$ heavy readers (reading numerous texts and novels as much as possible and as many times as possible in a month);

$>$ moderate readers (reading a few texts and novels as seem convenient for them);

$>$ dormant readers (those who enjoyed reading and they regarded themselves readers but did not take time to read regularly and update their knowledge).

Research Question 2: Is there a significant effect of reading habit towards college students' academic writing of English Language Education at UAD? The regression score of reading habits is 0,837 which indicates an increasing reading habit can also increase the writing skill at the 0,837 with the constant 2.006. Such significant relationship then was tested by using ANOVA. The results show that F score is 352,524 at the significant $0,000 \leq 0,05$. Thus, it can be said that the reading habits of college students of UAD have a significant influence on their writing skill. Those can be seen in Table 5 and Table 6 as follows:

Table 5. The Result of Regression Coefficients Reading Habits (X) towards Writing Skills (Y)

\begin{tabular}{|c|c|c|c|c|c|c|}
\hline \multirow{2}{*}{\multicolumn{2}{|c|}{ Model }} & \multicolumn{2}{|c|}{$\begin{array}{l}\text { Unstandardized } \\
\text { Coefficients }\end{array}$} & \multirow{2}{*}{$\begin{array}{c}\begin{array}{c}\text { Standardized } \\
\text { Coefficients }\end{array} \\
\text { Beta }\end{array}$} & \multirow[t]{2}{*}{$\mathbf{t}$} & \multirow[t]{2}{*}{ Sig } \\
\hline & & B & Std. Error & & & \\
\hline 1 & $\begin{array}{c}\text { (Constant) } \\
\mathrm{X}\end{array}$ & $\begin{array}{r}2,006 \\
, 837\end{array}$ & $\begin{array}{r}6,335 \\
, 045 \\
\end{array}$ & ,936 & $\begin{array}{r}, 317 \\
18,776 \\
\end{array}$ & $\begin{array}{r}, 753 \\
, 000 \\
\end{array}$ \\
\hline
\end{tabular}

Table 6. ANOVA

\begin{tabular}{rllllll}
\hline Model & & $\begin{array}{l}\text { Sum of } \\
\text { Square }\end{array}$ & df & $\begin{array}{l}\text { Mean } \\
\text { Sqquare }\end{array}$ & F & Sig \\
\hline $\mathbf{1}$ & Regression & 3608,027 & 1 & 3608,027 & 352,524 &, $000^{6}$ \\
& $\begin{array}{l}\text { Residual } \\
\text { Total }\end{array}$ & 511,742 & 50 & 10,235 & & \\
\hline
\end{tabular}

a. Dependent variable: $\mathrm{Y}$

b. Predictors: (Constant), $\mathrm{X}$

The strength of the correlation is examined by using Pearson Correlation. Its coefficient correlation is 0,936 which is much bigger than r-table of 0.239 . It means the better the college students' reading habit of UAD, the higher their writing skill level will be. The amount of the contribution of reading habits to the writing skills is shown by R square in the Model Summary below:

Table 7. Model Summary

\begin{tabular}{lrrrr}
\hline Model & R & R Square & $\begin{array}{c}\text { Adjusted R } \\
\text { Square }\end{array}$ & Std. Error of the Estimate \\
\hline $\mathbf{1}$ &, $936^{\mathrm{a}}$ &, 876 &, 873 & 3,19920 \\
\hline
\end{tabular}

a. Predictors: (Constant), $\mathrm{X}$

b. Dependent Variable: $\mathrm{Y}$

The findings above confirm that writing is not an easy task as it needs an ample of vocabularies, wide knowledge of various genres, and it is in line with Kellogg's statement (Kellogg, 2008) that writing is a major cognitive challenge, because it is at once a test of memory, language, and thinking ability.

Since writing skill is assumed to correlate with a reading habit, the study shows that most of the respondents or 35 students ( $68 \%$ ) do not have any published writings in a national or international journal or articles in the newspaper. It is in accordance with the statement given by Alwasilah (2004); Wibowo, (2015); and Wahyuni, Oktavia, \& Marlina (2019).

Though they are graduated from a Bachelor of English Language Education and have a medium level of reading habit, they almost never publish essay, paper, research report, or article. Only a few of them (5 students) published their writing to national journal and one (1) student has international publication. Such small number of published writing can be caused by their writing qualities reading habits contribute $87,6 \%$ 
to the writing quality and the rest $12,4 \%$ is caused by other factors such as publication fee, journal priority, the novelty of the research, etc.

Most importantly, major problems of their writing are grammar, syntax, vocabulary, and paragraph development are also emerged. Most errors are found in the use of the passive sentence, conditional clause, conjunction, noun clause, and cohesive items. In writing an academic essay they tend to use google translate which is frequently made inappropriate option of vocabulary. All of these stuffs should be taken into consideration by the college students since the problems will halt their competence in both reading and writing skills. Author (Kassymova G. K., 2018) states that the term 'competence' which is a key solution for the survival of organizations in the labor market and gives explanation on term 'competence'. It is very important to develop competence for students while they are studying at university.

Conclusions. The reading habits of college students at the graduate program of English Language Education, UAD are categorized into the medium level. This means that they already encouraged their capability to read a lot regularly pertaining to the topics they are eager to read. In addition, they have also showed that they have a good activity improve their knowledge related to everything via reading habit. Meanwhile, the level of writing skill of the students at the graduate program of English Language Education are also in the medium level. It is less than the reading habit. Hence, it can be meant that the college students need to elevate their competence of writing so that they can balance both their competence reading towards writing. Likewise, this study confirms that the reading habit has effected on their academic writing. It is due to many errors made by them for examples they lack English grammar, syntax, choice of words, and the cohesive item of the paragraph. In other words, those lacks of skills should be mastered and learnt by the college students since they are prepared to behold the future for their successful career.

Acknowledgement. We would like to gratefully thank the Head of Department of the English Language Education, a graduate school of Universitas Ahmad Dahlan Yogyakarta for the support given during the research.

Cite this article as: Atayeva M., Putro, N. H. P. S., Kassymova G., Kosbay S. (2019) Impact of reading on students' writing ability. Materials of International Practical Internet Conference "Challenges of Science". ISBN 978-601-323-144-0. Issue II, 2019. Page 5-13. https://doi.org/10.31643/2019.001

\section{References}

[1] Adetunji, A. (2007). Factors affecting reading habit of secondary school students in Osogbo metropolis. The Social Sciences, 2(1), 102-105.

[2] Adetunji, A., \& Oladeji, B. O. (2007). Comparative study of the reading habit of boarding and day secondary school students in Osogbo, Osun State, Nigeria. Pakistan Journal of Social Science, 4(4), 509-512.

[3] Akbar, F. (2014). The role of reading in improving speaking skill in the context of teaching English as a foreign language. International Journal of English Language \& Translation Studies, 2(4), 92-98.

[4] Al Nazhari, H., \& Delfi, S. (2016). A Study on English reading habits of students of English study program at Riau University. Jurnal Online Mahasiswa (JOM) Bidang Keguruan dan Ilmu Pendidikan, 3(2), 1-8.

[5] Alwasilah, A. C. (2004). Survai perkuliahan menulis kolaboratif jurusan pendidikan bahasa Inggris. Laporan penelitian tidak diterbitkan. FPBS UPI. Bandung.

[6] Arndt, H. L., \& Woore, R. (2018). Vocabulary learning from watching YouTube videos and reading blog posts. Language Learning \& Technology, 22(3), 124-142.

[7] Ayun, Q. \& Yunus, M. (2017). The efficacy of the reciprocal teaching method in teaching reading comprehension to EFL Students. ELT Echo: The Journal of English Language Teaching in Foreign Language Context, 2(2), 134-146. https://doi.org/10.24235/eltecho.v2i2.2174

[8] Bailey, S. (2003). Academic writing. A practical guide for students. (1st ed.). London: Routledge. Nelson Thornes Ltd.

[9] Chitez, M., Kruse, O., \& Castello, M. (2015). The European writing survey (EUWRIT): Background, structure, implementation, and some results. Language Competence Centre. http//researchgate.net/publication/282156102

[10] Connor, U. (1996). Contrastive rhetoric cross-cultural aspects of second language writing. Cambridge Applied Linguistics. Cambridge: Cambridge University Press. https://doi.org/10.1017/cbo9781139524599.007 


\section{Materials of International Practical Internet Conference "Challenges of Science”}

[11] Cottrell, S. (2017). Critical thinking skills: Effective analysis, argument, and reflection. Macmillan International Higher Education.

[12] Dardjowidjojo, S. (1997). Cultural constraints in the teaching of English in Indonesia. Paper presented at The TEFLIN 45th National Conference: Maranatha Christian University, Bandung.

[13] Dipika, M. and Md. Mehedi, H. (2013). Newspaper reading habits of private University students: A case study on world University of Bangladesh. IOSR Journal of Business and Management. 12(1), pp 87-91. https://doi.org/10.9790/487x1218791

[14] DOCPLAYER. (2017). Indonesian people reading habit is very Low: How libraries can enhance the people reading habit. Mustafa, B. Retrieved March 5, 2012, https://doi.org/10.31227/osf.io/5apkf

[15] Ellis, A. W. (2016). Reading, writing and dyslexia (classic edition): A Cognitive Analysis. Psychology Press.

[16] Erdem, A. (2014). A research on reading habits of university students: (Sample of Ankara university and Erciyes university). Proceedia-Social Behavioral Sciences.2983-3990. https://doi.org/10.1016/j.sbspro.2015.01.1145

[17] Fatiloro, O. F., Adesola, O. A., Hameed, B. A., \& Adewumi, O. M. (2017). A Survey on the reading habits among Colleges of Education students in the information age. Journal of Education and Practice, 8(8), 106-110.

[18] Florence, F. (2017). A survey on the reading habits among colleges of education students in the Information age. Journal of Education and Practice, 2222-1735; 2222-288X.

[19] Grabe, W. and Kaplan, R. (1996). Theory and practice of writing. London: Addison Wesley Longman.

[20] Hattab, A. (2018). Promoting critical thinking skills for EFL learners' through teaching reading and writing.

[21] Hedge T. (2005). Writing. New York: Oxford University Press.

[22] Horkoff, T., and McLean, S. (2015). Writing for success. 1st Canadian edition. Canada: Open Textbooks.

[23] Husin, M. S., \& Nurbayani, E. (2017). The ability of Indonesian EFL learners in writing academic papers. Dinamika Ilmu, $17(2), 237-250$.

[24] Iftanti (2012). A survey of the English reading habits of EFL students in Indonesia. TEFLIN Journal, 3 (12). 149-164.

[25] Iftanti, E. (2015). What makes EFL students establish good reading habits in English. International Journal of Education and Research, 3(5), 365-374.

[26] Imran, N. (2005). The interplay of culture, individual differences and adult EFL reading performance: From teacherdependence to the development of autonomous readers. Paper presented at the The 1st International Seminar on Literacy Education in Developing Countries: Semarang, Indonesia.

[27] Iswandari, Y. A. (2013). The influence of dialogue journal writing in reducing efl students' writing anxiety. Indonesian JELT, 9(1), 42-57.

[28] Januarty, R. (2018). Extensive reading (ER) practices and the development of language fluency. Lingua, 12(3), $267-272$. https://doi.org/10.21512/lc.v12i3.4063

[29] Juriati, D. E., Ariyanti, A., \& Fitriana, R. (2018). The correlation between reading comprehension and writing ability in descriptive text. Southeast Asian Journal of Islamic Education, 1(1), 01-14.

[30] Kanmani, A., \& Muniandy, P. (2013). The effectiveness of extensive reading on English vocabulary acquisition.

[31] Kassymova, G. (2018). Competence and its implications. Challenges of Science. Conference: International Practical Internet Conference "Challenges of Science", November 2018. P.366-368. https://doi.org/10.31643/2018.063

[32] Kellogg, R. (2008). Training writing skills: A cognitive developmental perspective. Journal of writing research, 1(1), 1-26.

[33] Kellogg, R. T. (2018). 23 Professional writing expertise. The Cambridge Handbook of Expertise and Expert Performance, 413. https://doi.org/10.1017/9781316480748.023

[34] Krashen, S. (2016). Compelling reading and problem-solving: The easy way (and the only way) to high levels of language, literacy, and life competence. In Epoch making in English language teaching and learning. Twenty-fifth international symposium on English teaching (pp. 115-125).

[35] Kridalaksana, H. (2002, January 16). Soal tidak ada universitas riset. Kemampuan menulis para dosen masih minim. (A matter of no research university. Lecurers' writing ability is still low). The Kompas.

[36] McKnight, K. S., \& Allen, L. H. (2018). Strategies to support struggling adolescent readers, grades 6-12. Rowman \& Littlefield.

[37] Miller, J. W. and Michael, C. M. (2016). World literacy: How countries rank and why it matters. London: Routledge.

[38] Muawanah, S. (2014). The Relationship between students' reading habit and their reading comprehension. (A Correlational study at the second grade students of SMA Dua Mei Ciputat). Department of English Education Faculty of Tarbiyah and Teacher's Training. (Undergraduate Thesis). 'Syarif Hidayatullah' State Islamic University. Jakarta.

[39] Nathanson, S., Pruslow, J., \& Levitt, R. (2008). The reading habits and literacy attitudes of inservice and prospective teachers: Results of a questionnaire survey. Journal of Teacher Education, 59(4), 313-321. https://doi.org/10.1177/0022487108321685

[40] Noviadhista, F. (2016, November 19). Berapa lama umumnya orang Indonesia nonton video dalam sehari?. Techno. ID.

[41] Ögeyik, M. C., \& Akyay, E. (2009). Investigating reading habits and preferences of student teachers at foreign language departments. The International Journal of Language Society and Culture, 28, $72-78$.

[42] Park, Y. (2011). How motivational constructs interact to predict elementary students' reading performance: Examples from attitudes and self-concept in reading. Learning and Individual Differences, 21(4), 347-358. https://doi.org/10.1016/j.lindif.2011.02.009

[43] Putro, N. H. P. S., \& Lee, J. (2018). Profiles of Readers in a Digital Age. Reading Psychology, 39(6), 585-601.

[44] Redman, P., \& Maples, W. (2017). Good essay writing: a social sciences guide. Sage.

[45] Santoso, D. A. A. (2015). The effects of reading habit and vocabulary mastery towards student's speaking skill. DEIKSIS, 6(03), 181-188. 
[46] Schwabe, F., McElvany, N., \& Trendtel, M. (2015). The school age gender gap in reading achievement: Examining the influences of item format and intrinsic reading motivation. Reading Research Quarterly, 50(2), 219-232. https://doi.org/10.1002/rrq.92

[47] Suhartono, S. (2014). Pengaruh kebiasaan membaca, kemampuan berpikir kritis, dan penguasaan struktur sintaksis terhadap keterampilan menulis ilmiah:(Survei pada Mahasiswa Pendidikan Bahasa dan Sastra Indonesia FKIP Universitas Bengkulu). Lentera Pendidikan: Jurnal Ilmu Tarbiyah dan Keguruan, 17(1), 43-66. https://doi.org/10.24252/lp.2014v17n1a4

[48] Sukandi, S. (2013, July). Teaching writing to Indonesian EFL learners: Challenges of the "Voice" and "Style" in adjusting cross cultural communication skills. Proceeding International Seminar: Research Gate.

[49] Suskie, L. (2018). Assessing student learning: A common sense guide. John Wiley \& Sons.

[50] Wahyuni, D. W. D., Oktavia, W. O. W., \& Marlina, L. M. L. (2019). Writing anxiety among Indonesian EFL college students: Levels, Causes, and Coping Strategies. Lingua Cultura, 13(1), 67-74.

[51] Wibowo, W. (2015). Kebiasaan membaca buku masyarakat indonesia rendah. Teaching. Oxford: Macmillan Heinemann English Language Teaching. 